\title{
REVIEW OF ASCOCERID CEPHALOPODS FROM THE UPPER SILURIAN OF THE PRAGUE BASIN (CENTRAL BOHEMIA) - HISTORY OF RESEARCH AND PALAEOBIOGEOGRAPHIC RELATIONSHIPS
}

\author{
MARTINA AUBRECHTOVÁ
}

Department of Palaeontology, National Museum, Václavské náměstí 68, 11000 Prague 1, the Czech Republic; e-mail: aubrechm@gmail.com.

Aubrechtová, M. (2019): Review of ascocerid cephalopods from the upper Silurian of the Prague Basin (Central Bohemia) history of research and palaeobiogeographic relationships. - Fossil Imprint, 75(1): 14-24, Praha. ISSN 2533-4050 (print), ISSN 2533-4069 (on-line).

\begin{abstract}
The order Ascocerida KuHN, 1949 includes rare and morphologically unique early Palaeozoic cephalopods, in which periodic shell truncation occurred during ontogeny; mature shells subsequently became inflated, with thin sigmoidal septa and phragmocone chambers situated above the living chamber. The ascocerids are at present known mainly from North America and Baltoscandic Europe. The group was first described by J. Barrande in the mid 1800's from the upper Silurian of Bohemia. Finds of ascocerid fossils in Bohemia are generally scarce but Barrande's collection includes tens of well-preserved specimens. These are briefly reviewed in the present paper and additional, more recently collected material is also discussed. In Bohemia (Prague Basin), ascocerids occur in limestones of Ludlow to late Př́idolí age. Their maximum diversity and abundance was reached close to the Ludlow/Prídolí boundary interval. Five out of the fourteen currently recognized Bohemian species are also known from late Silurian strata in Sweden (the island of Gotland). The ascocerids thus illustrate palaeobiogeographic relationships between the Prague Basin and Baltica during the late Silurian.
\end{abstract}

Key words: Cephalopoda, Ascocerida, palaeogeography, Silurian, Prague Basin, Gotland

Received: January 2, 2019| Accepted: May 2, 2019 | Issued: August 29, 2019

\section{Introduction}

Cephalopods of the order Ascocerida Kunn, 1949 are known from the Ordovician and Silurian strata of North America (e.g. Foerste 1930, Miller 1932, Flower 1941, 1963) and Europe (e.g. Barrande 1865, 1867, 1877a, b, Lindström 1890, Dzik 1984, Holland 1999). The group comprises morphologically peculiar cephalopods, in which repeated shell truncation and morphological transitions occurred during ontogeny (see Furnish and Glenister 1964, Turek and Manda 2012 for discussion and references; Text-fig. 1). In ascocerids, the juvenile shells are slender, exogastrically curved longicones with a narrow tubular siphuncle, orthochoanitic septal necks and a relatively small initial chamber with a cicatrix. The juvenile shell is periodically shed and the morphology of adoral parts of the shell gradually changes (Text-fig. 1). The final fully mature growth stage (ephebic shell) is inflated and characterized by the thin sigmoidal lacunose septa that are situated above the living chamber; the siphuncle consists of strongly expanded segments with thin, homogenous connecting rings and cyrtochoanitic, recumbent septal necks (see Furnish and Glenister 1964, Mutvei 2012, 2013; Text-fig. 1).
Due to repeated shell truncation and because the shell wall was rather thin (Flower 1941, Furnish and Glenister 1964), finds of ascocerid specimens are uncommon and specimens with both juvenile and mature shell portions joined together are extremely rare (Lindström 1890, Cichowolski et al. 2018). As a consequence, knowledge of the early ontogeny in ascocerids, and in particular, the process of truncation and the changes to the soft body upon maturity remains poor. Agreement has also not been reached regarding the phylogenetic relationships of the group. Ascocerids have been thought to be related to the Discosorida (Mutvei 2012, 2013), Oncocerida (Miller 1932), Orthocerida (Flower 1941, 1963, Dzik 1984, Teichert 1988) or most recently the Barrandeocerida (Kröger 2013, King and Evans 2019). Palaeoecology of the group have been speculated about widely, as well, namely the existence of natural truncation and its effects on the shell orientation and mode of life of the animals (Furnish and Glenister 1964, Dzik 1984, Teichert 1988, Westermann 1998, Mutvei 2012, and Kröger 2013).

Especially important to the resolution of some of the foregoing issues are two collections of late Silurian ascocerids: from the Swedish island of Gotland (Lindström 1890) and from Bohemia (Barrande 1848, 1855a, b, 1865, 

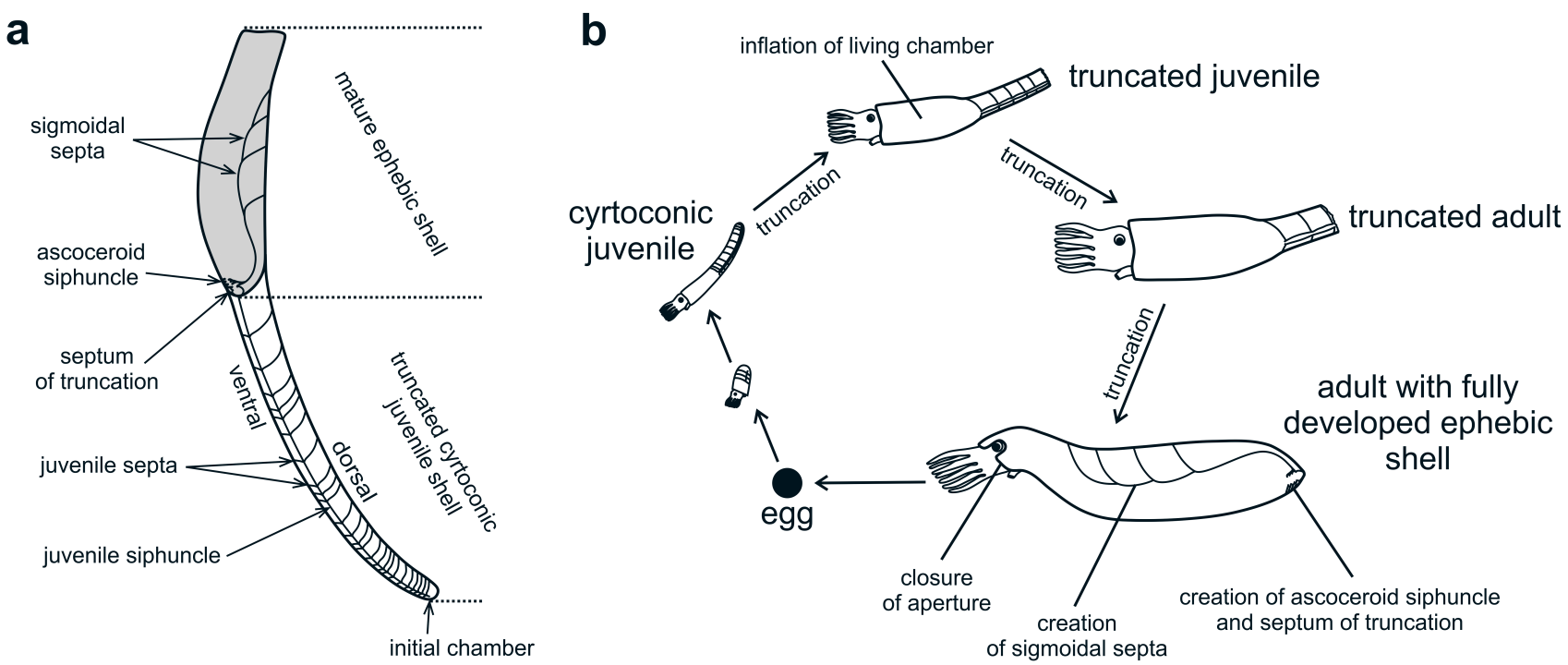

Text-fig. 1. Schematic drawing showing basic morphological characters of ascocerid cephalopods (a) and changes to the morphology of the shell during ontogeny (b). Adapted from Lindström (1890), Furnish and Glenister (1964).

1867, 1877a, b). Both collections are significant in their large sizes (each includes $>100$ specimens), as well as in containing some uniquely preserved specimens showing e.g. initial chambers or imprints of muscle scars. Despite their value, neither collection has formed the subject of a modern detailed revision. Here, the historical collections, as well as some more recently collected ascocerids from Bohemia are briefly reviewed. Their stratigraphic occurrence is summarised and the palaeogeographical implications are emphasized.

\section{Geological settings}

All specimens of Bohemian ascocerids come from the limestone sediments of the Kopanina and Požáry formations (Ludlow - Př́idolí series, Silurian) of the Prague Basin (Text-figs 2, 3). The latter is a denudation relict of a rifttype sedimentary depression filled with clastics, carbonates, ferrolites and volcanics that were continuously deposited from between the Early Ordovician and the Middle Devonian (Havlíček 1981, 1982, Chlupáč et al. 1998, Vacek and Žák 2017). Sedimentation ended with the Variscan Orogeny (Chlupáč et al. 1972, 1998). During the early Palaeozoic, the Prague Basin was supposedly situated on the peri-Gondwanan microcontinent (microplate) Perunica (Havlíček et al. 1994, Fatka and Mergl 2009), which drifted from high southern latitudes towards lower latitudes during this interval (Havlíček 1998, Cocks and Torsvik 2006). This movement is reflected by the transition from clastic (Ordovician) to carbonate sedimentation (Silurian to Devonian), as well as by changes in the composition of fossil assemblages (see Chlupáč et al. 1998 and references therein).

Sedimentation of the Silurian strata of the Prague Basin was influenced by synsedimentary tectonic activity, basin segmentation, intense volcanism as well as eustatic sea level changes, generating a diverse set of facies characterized by frequent lateral and vertical transitions. The varying compositions of the fossil assemblages, as well as their preservation, also reflect the range of palaeoenvironmental and depositional conditions. For detailed descriptions of the Silurian strata of the Prague Basin and discussions of their lithology, fossil content and stratigraphy, see the works of Kříž (1991, 1992, 1998a), Kříž et al. (1986, 1993), Štorch (1994, 1995a, b, 2006), Štorch et al. (2014), Manda and Křriž (2006, 2007), Manda and Frýda (2010), Manda et al. (2012), Frýda and Manda (2013), Slavík et al. (2014), Štorch et al. (2014, 2018) and Tasáryová et al. (2018) and references therein. A very brief summary is given below.

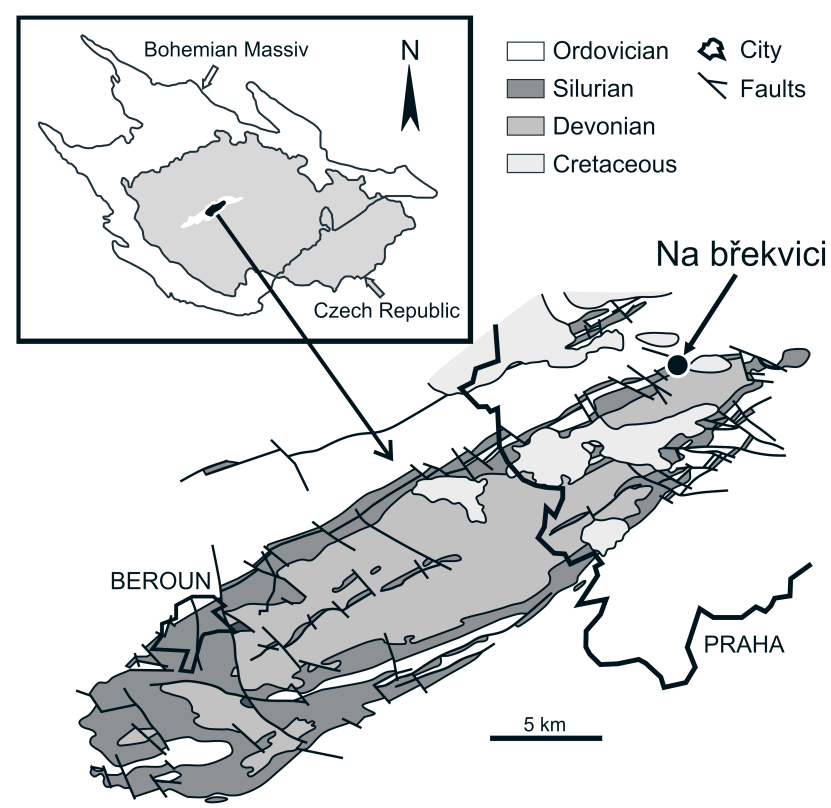

Text-fig. 2. Distribution of Silurian rocks within the Prague Basin (central Bohemia), the locality of the stratigraphically oldest known Bohemian ascocerid is indicated (see text above). Modified from Kříž (1998a), Manda and Křriž (2007). 
The early Silurian (Rhuddanian) marine transgression resulted in the deposition of black, anoxic graptolite shales (Štorch 2015). The development of these facies persisted in deeper parts of the Prague Basin until the end of the Silurian (Štorch 1986, 2006, Kříž 1998a). During the Aeronian tuffaceous limestones interbedded with the black shales developed around the Hýskov Volcanic Centre where an increasing admixture of carbonates initiated the deposition of calcareous shales and limestones during the Telychian and Sheinwoodian. Increasing volcanism during the Sheinwoodian, Homerian and Gorstian gave rise to four volcanic centres (Řeporyje, Svatý Jan, Kosov and Nová Ves; e.g. Tasáryová et al. 2014, 2018) associated with carbonate sedimentation (including cephalopod limestones, see e.g. Ferretti and Kříž 1995, Kříž 1999, Manda and Kř́iž 2007), while in the deeper parts of the basin, the deposition of calcareous shales predominated. During the Ludfordian and Př́idolí, volcanism was quiescent as the sedimentation of limestones and calcareous shales continued. Associated cephalopod facies also developed (e.g. Ferretti and Kř́žz 1995, Kř́rž 1998b, Manda and Kř́iž 2006). (volcanics, tuffs/tuffites, tuffaceous limestones and various other limestones), while successions developed in deeper parts of the basin consist of monotonous calcareous shales. Cephalopod limestones developed around the volcanic centres during a regression in the early Ludfordian (Ferretti and Kříž 1995, Manda and Kříž 2007), or in deeper but uplifting areas of the basin (Krríž 1992, 1998a). Calcareous shales were deposited where the Basin was deeper or where regression was compensated by subsidence (Kř́ž 1992, 1998a). During the late Ludfordian, transgression generated distinct facies changes in some regions, but in others, sedimentation of shallow-water cephalopod bearing limestones persisted; locally into the earliest Přídolían (Kř́ž et al. 1986, Kř́iž 1992, 1998a, b). The maximum of the latest Ludlowian regression was marked by the development of skeletal limestones containing rich invertebrate assemblages (Kříž 1992, 1998a).

The uppermost Silurian strata (uppermost Ludlow Prrídolí series) of the Prague Basin are assigned to the Požáry Formation (Text-fig. 3; see Prantl and Přibyl 1948, Kř́žz et al. 1986, Kř́̌ž 1989). The Požáry Formation has a

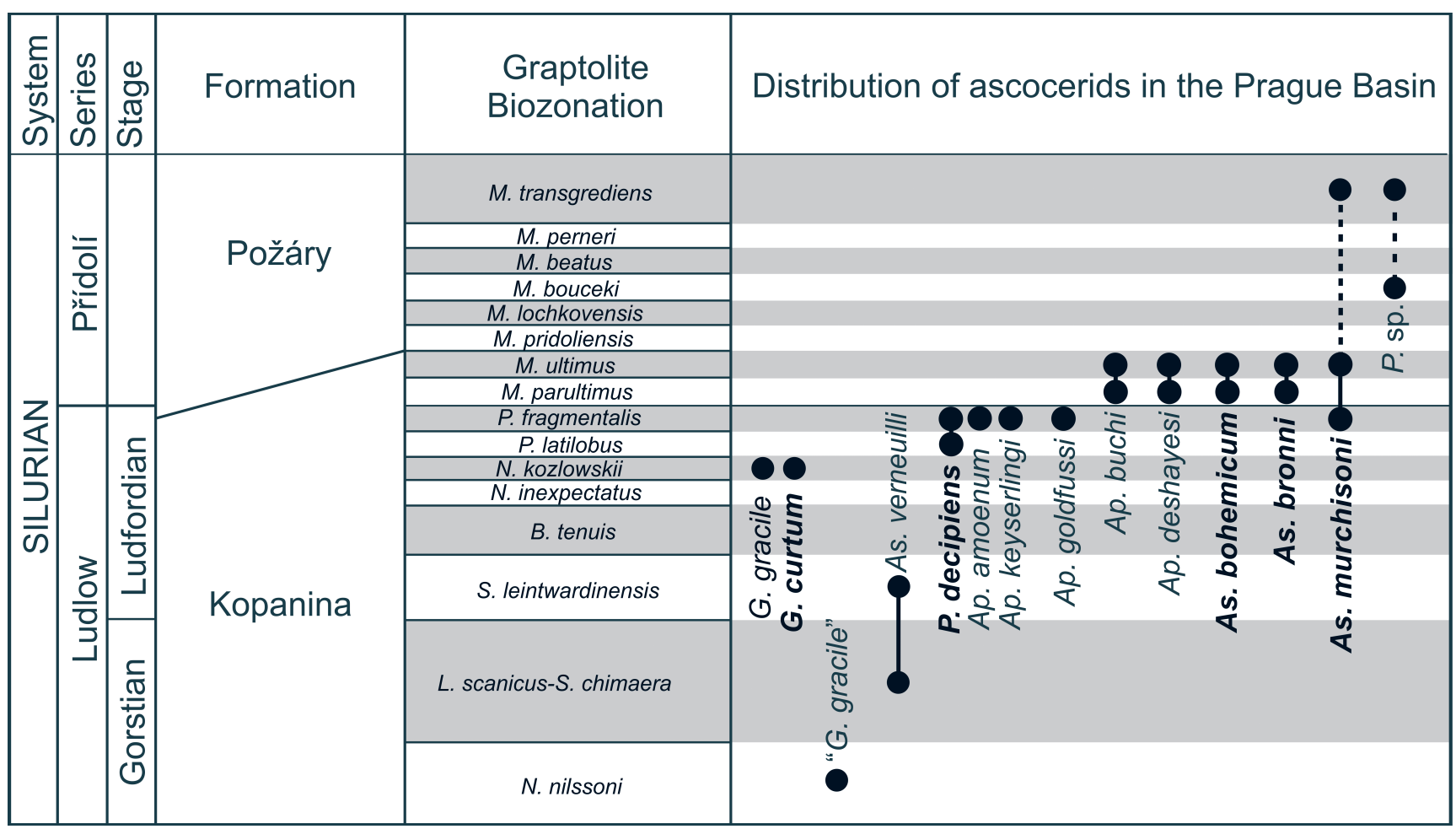

Text-fig. 3. Scheme showing the stratigraphic distribution of ascocerid cephalopods in the late Silurian strata of the Prague Basin. Names of species in bold indicate taxa known from the Swedish island of Gotland (see text below). Abbreviations: $A p .=$ Aphragmites, As. $=$ Ascoceras, $G .=$ Glossoceras, $P .=$ Pseudascoceras. Stratigraphic occurrence of ascocerid species adapted after Zedník (2003). Graptolite zonation after Kř́̌ž (1992, 1998a), Manda and Kř́̌́z (2006, 2007), Štorch et al. (2014).

The Kopanina Formation (Ludlow - lowermost Př́idolí series; Text-fig. 3), defined by Prantl and Přibyl (1948), is of variable thickness (ca. 50-150 m) and lithologically complex, especially in its lower part (Gorstian Stage). There, facies that continue upwards from the underlying Motol Formation are differentiated and characteristic for each of the tectonic segments of the basin (Krríž 1992, 1998a, Kříž et al. 1993, Manda and Kř́iž 2006). These facies are very diverse, especially in the vicinity of the former volcanic centres thickness of 5-90 m and its boundary with the preceding Kopanina Formation is diachronous (Text-fig. 3) (Krríž et al. 1986, Kř́ž 1998a). Two international GSSP stratotypes have been established in the late Silurian strata of the Prague Basin, that define the boundary between the Ludlow and Přídolí series and the Přídolí Series and the Lower Devonian Series (see Chlupáč et al. 1972, Chlupáč 1998, Chlupáč and Vacek 2003, Fatka et al. 2003, Manda and Frýda 2010 for discussion and references). 
The Požáry Formation is facially less varied than the Kopanina Formation due to a significant transgression that took place around the Ludlow/Př́idolí boundary interval (Kříž et al. 1986, Kříž 1998a, Vacek et al. 2018). Consequently, the Požáry Formation in all parts of the Prague Basin consists of dark, platy biomicritic and bioclastic limestones with calcareous shale intercalations. In the late Přídolí, bioclastic crinoidal and cephalopod limestones (Kříž et al. 1986, Ferretti and Kř́žz 1995, Kříž 1998b) were deposited as the basin shallowed (Vacek et al. 2018).

\section{Studied material}

The ascocerid specimens specifically addressed herein are contained in the historical collection of J. Barrande and later collections, all housed at the National Museum in Prague (NM-L). Several additional specimens are held in the collections of the Czech Geological Survey (Prague) and the Faculty of Science of the Charles University (Prague). One Bohemian specimen figured by Barrande (1877a: pl. 513, figs 14-16) housed in the J. M. Schary collection (Museum of Comparative Zoology, Harvard University, Massachusetts, U.S.A.) was not studied here.

The specimens were photographed using digital cameras Olympus E-30 and Canon EOS 6D. Some specimens were whitened with ammonium chloride $\left(\mathrm{NH}_{4} \mathrm{Cl}\right)$ prior photographing to highlight surface ornamentation (Parsley et al. 2018).

\section{History of research of ascocerid cephalopods}

Ascocerid cephalopods were first reported by J. Barrande $(1848,1855 \mathrm{a}, \mathrm{b})$ from the late Silurian strata of Bohemia. Barrande classified these cephalopod fossils under the single genus Ascoceras BARRANDE, 1848. Later, in his classical studies on the Silurian fossils of Bohemia, Barrande (1865, $1867,1877 \mathrm{a}, \mathrm{b})$ described and accurately illustrated tens of ascocerid specimens that he assigned to two additional genera and several species and established for them the family Ascocératides (= Ascoceratidae BARRANDE, 1867). Barrande (1860) already recognised the process of natural truncation of ascocerid juvenile shells, although he considered the ascocerid living chamber as homologous to the endocerid siphuncle.

During the $19^{\text {th }}$ century, ascocerids were also reported from the Ordovician and Silurian of North America by Billings (1857, 1865, 1866), Whiteaves (1884), Newell (1888) and Worthen (1890), from the Silurian of England by Salter (1858) and Blake (1882) and from the Silurian of Sweden by Lindström (1890). Hyatt (1883-1884) discussed the higherlevel taxonomy of ascocerids. Hyatt in Zittel (1900) briefly summarised those ascocerid taxa known to date

As indicated in the above, the large collection of ascocerids described by Lindström (1890) is important because the preservation of these specimens enables study of the ontogeny and the process of truncation. Lindström provided descriptions and very detailed illustrations of ca. 130 specimens, including embryonic shells with the initial chamber. Some of these specimens represent subadult growth stages in which the juvenile longiconic shell is attached to the mature ephebic shell. Lindström (1890) also established the enigmatic genus Choanoceras, which is longiconic in shape and lacks the typical bulbous living chamber and sigmoidal septa characteristic of Ascoceras and related taxa (see also later works of Flower 1941, Mutvei 2012 and Kröger 2013).

During the first decades of the $20^{\text {th }}$ century, Foerste and Savage (1927), Foerste (1928, 1929, 1930, 1932) and Miller (1932) revised the Ordovician ascocerids. Miller (1932) also revised and re-figured Silurian ascocerids from Bohemia and Gotland and speculated on the phylogenetic relationships of ascocerids to cephalopods at present assigned to the order Oncocerida.

Ordovician ascocerids from North America were addressed many times by Flower $(1941,1952,1963)$ and Flower in Flower and Kummel (1950). Flower (1941) defined a new Middle Ordovician family Hebetoceratidae for cephalopods with longiconic or only adorally inflated shells in which the sutures are oblique but not sigmoidal. He concluded that the hebetoceratids were ancestral to all stratigraphically younger ascocerids. Sweet (1959) figured the ventromyarian muscle scars in the Upper Ordovician genus Billingsites HyATT, 1884 from Canada (cf. Mutvei 2013 and text below). Strand (1933) and Sweet (1958) described a handful of ascocerid specimens from the Upper Ordovician of Norway and assigned them to genera Billingsites, Probillingsites Foerste, 1928 and Schuchertoceras MiLLER, 1932. Furnish and Glenister (1964) summarised previous literature and the state of knowledge of the morphology, palaeoecology, stratigraphy and palaeogeography of ascocerids. These authors objected to the phylogenetic concepts of Flower $(1941,1963)$ and Flower in Flower and Kummel (1950) because in their view, Flower's conclusions were based on poorly preserved material. Kesling (1961) described a new species of Billingsites from the Upper Ordovician of Michigan (but see Kesling 1962) and speculated on its possible mode of life. Frey (1985) examined a well-preserved specimen of Schuchertoceras obscurum Flower, 1946 from the Upper Ordovician of Ohio, documenting the previously poorly known internal structures of that species. Teichert (1988) and Westermann (1998) discussed the palaeoecology of ascocerids. The latter author, however, did consider the concept of repeated shell truncation (cf. Turek and Manda 2012 and references therein). Some finds of Silurian ascocerids are known also from Estonia (Kaljo 1970) and from the erratics of Baltic origin in Germany (Neben and Krüger 1973) as well as Poland (Dzik 1984). Holland (1999) revised Silurian ascocerids from England.

Kröger (2007) studied juvenile and minute adult shells of ascocerids of the species Parvihebetoceras wahli KRÖGER, 2007 (family Hebetoceratidae) from the Hirnantian of Estonia (Porkuni Regional Stage, Upper Ordovician). This material provides the only record of ascocerid embryonic shells other than those reported by Lindström (1890) from the Silurian of Gotland. Kröger (2007) regarded the presence of a cicatrix on the initial chamber of ascocerids and pseudorthocerids as evidence of a close phylogenetic relationship between the two groups.

In examining the muscle attachment scars and structure of the siphuncle in the ascocerid Choanoceras, Mutvei (2012, 2013) speculated on a phylogenetic relationship between the orders Ascocerida and Discosorida, and Mutvei 
(2013) assigned the Ascocerida into his newly established superorder Multiceratoidea.

Kröger (2013) investigated a remarkably abundant and diverse ascocerid assemblage from the late Katian - early Hirnantian Boda Limestone Formation of central Sweden. These were assigned to several (new) species of the genera Probillingsites, Schuchertoceras, Redpathoceras FLOwER, 1963 (all family Ascoceratidae) and Parvihebetoceras KRÖGER, 2007 (family Hebetoceratidae). Based on the rich and well-preserved material, Kröger (2013) suggested possible phylogenetic relationships of the Ascocerida to the order Barrandeocerida.

More recently, Aubrechtová and Meidla (2016) described an ascocerid specimen from the upper Silurian of Estonia and discussed some aspects of stratigraphy and palaeogeography of the group. Cichowolski et al. (2018) reported ascocerids from the Ordovician-Silurian transition interval of Argentina. These specimens are interesting in that they show juvenile shell portions joined to ephebic shells; they are also the only ascocerids currently known from a region with a supposed high-latitude palaeoposition.

\section{Ascocerid cephalopods from the late Silurian of the Prague Basin}

The ascocerid collection collected by Joachim Barrande in the $19^{\text {th }}$ century consists of at least 175 specimens, of which 53 were figured in the Systême silurien du Centre

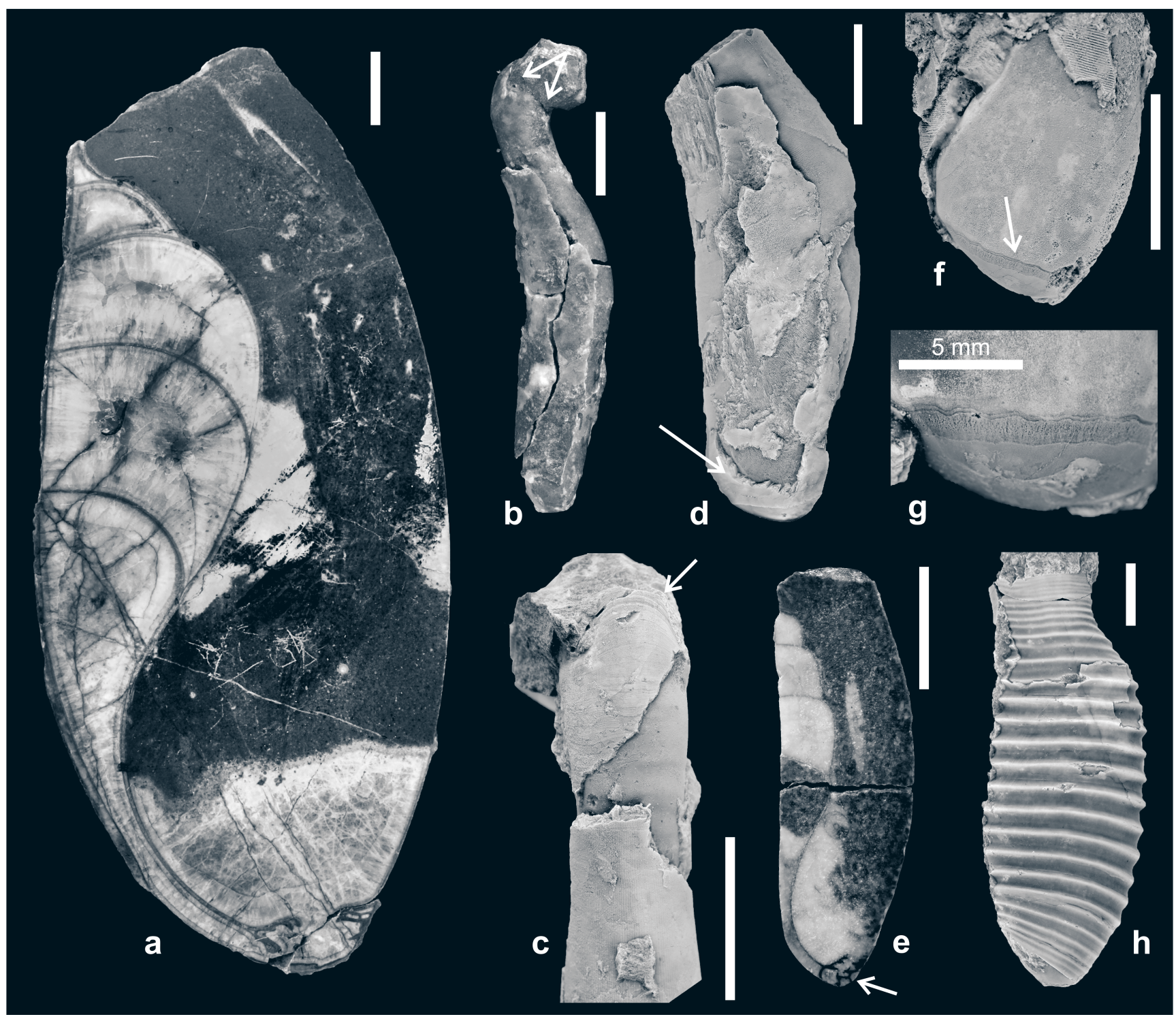

Text-fig. 4. Ascocerid cephalopods from the upper Silurian of the Prague Basin (Bohemia). a) Ascoceras bohemicum, NM-L 9254, longitudinal section, lateral view showing septa and siphuncle. b, c) Glossoceras curtum, NM-L 9278, lateral (b) and dorsal (c) views, arrows point to aperture, note the fine reticulate sculpture in (c). d) Ascoceras murchisoni, NM-L 21655, lateral view, arrow points to the position of the single preserved chamber of the juvenile growth stage. e) Pseudascoceras decipiens, NM-L 42390, longitudinal section, lateral view showing septa and siphuncle, arrow points to duplicature (see text above). f, g) Ascoceras bronni, NM-L 42417, lateral view showing the latest septum and muscle scars (arrow in (f)), note the transverse sculpture in (f), detail of muscle scars is seen in (g). h) Aphragmites buchi, NM-L 9260, lateral view, note prominent annulation. All scale bars equal to $10 \mathrm{~mm}$ unless indicated otherwise. Specimens on (c), (d) and (f-h) coated with ammonium chloride before photographing. Photographs taken by Lenka Váchová (National Museum, Prague) and the present author. 
de la Bohême (Barrande 1865, 1877a). The specimens are well-preserved, showing shell ornamentation, internal structures and complete apertures. In addition, the specimens NM-L 9263 and -L 13805 display muscle-scars and specimen NM-L 21655 shows one chamber of the juvenile shell portion (Barrande 1877a: pl. 491, figs 3-7; Text-fig. 4d). Unfortunately, the original oblique cut of the latter specimen does not permit further study of internal structures.

Barrande assigned his specimens to twelve species belonging to three genera: Aphragmites BARRANDE, 1865, Ascoceras and Glossoceras BARRAnde, 1865. Ascoceras is the type genus of the family Ascoceratidae, and includes the largest known ascocerids (A. bohemicum BARRANDE, 1855 and A. manubrium LindSTRÖM, 1890; Text-fig. 4a), in which the ephebic shell may be up to $130 \mathrm{~mm}$ in length. Generally, however, the ephebic shell in Ascoceras is much shorter, about 40-60 $\mathrm{mm}$ in length, rather robust, smooth or sculptured by straight, transverse striae; the aperture is simple, three or four phragmocone chambers are present within the shell, the basal septum or any remnant thereof is not present, either (cf. Pseudascoceras in the text below). The genus Aphragmites is comparable in shell shape and overall proportions to Ascoceras but the shell in the former genus differs in being markedly annulated (Text-fig. 4h). Glossoceras has a narrow, slender ephebic shell with as many as six phragmocone chambers. The aperture is highly modified showing two lateral (ocular) sinuses, a smaller ventral sinus and prominent dorsal saddle (Text-fig. 4b, c).

Since Barrande's time, a handful of new ascocerid material has been collected from the Prague Basin, and Bohemian ascocerids have been discussed only twice - by Lindström (1890) and by Miller (1932). The only study that has specifically addressed Bohemian ascocerids is an unpublished MSc. thesis by Ladislav Zedník (2003). In his thesis, the author described a surprisingly large number (71) of newly collected and stratigraphically well-determined specimens (Text-fig. 3) that were gathered during intensive field-work during the 1990's by L. Zedník, L. Čížek and Š. Manda (Turek and Manda 2012). This new material extends our knowledge of several aspects related to Bohemian Ascocerida. For example, both in the historical collections of J. Barrande and in the newly collected material, L. Zedník (2003) identified unequivocal representatives of the genus Pseudascoceras Miller, 1932 previously known only from Gotland (Lindström 1890). Pseudascoceras is distinguished from other Silurian ascocerids through exhibiting the duplicature at the connecting rings (e.g. NM-L 42390; Text-fig. 4e), regarded as a remnant of the basal septum (Lindström 1890, Miller 1932, Flower 1941), and thus constituting a phylogenetically important character.

Another specimen of Ascoceras (NM-L 42417) displays muscle scars on the lateral side of the shell (Text-fig. $4 \mathrm{f}, \mathrm{g})$. The muscle scars in ascocerids are thought to be ventromyarian (Sweet 1959) but their preservation is very rare leading to a lack of knowledge on their morphology. The only exception is a specimen of Choanoceras from the upper Silurian of Gotland (Lindström 1890: pl. VII, figs 13, 14). The specimen shows a series of pits and longitudinal ridges that Mutvei (2013) interpreted as multiple muscle scars similar to those known from the Oncocerida and Discosorida. The muscle scars in the Bohemian specimen form a transverse band, which has a corrugated outline but no pits or longitudinal ridges on the living chamber are visible. Unfortunately, any interpretation regarding the observed structures is difficult to make for now since the specimen from Bohemia is incompletely preserved, lacking the ventral and dorsal part of the muscle scars.

\section{Stratigraphy of Bohemian ascocerids and their palaeo- biogeographic implications}

In the Prague Basin, ascocerids are known only from late Silurian strata. The stratigraphically oldest Bohemian ascocerid was depicted by Barrande (1877: pl. 513, figs 10-13) and assigned by him to the species "Glossoceras gracile". Based on Barrande's illustration, the specimen should be assigned to Ascoceras rather than Glossoceras, but this cannot be confirmed as the specimen is probably lost (Zedník 2003). The specimen originated from the locality Butovice - Na Břekvici (Kř́̌ž 1992; Text-fig. 2), which corresponds to the $N$. nilssoni graptolite Biozone (lower Gorstian Stage, Ludlow Series; Text-fig. 3).

Three ascocerid species occur in Ludfordian strata (Zedník 2003; Text-fig. 3): Ascoceras verneuili BARRAnde, 1865 (S. leintwardinensis Biozone), Glossoceras curtum Miller, 1932 (= Glossoceras gracile var. curta BARRANDE, 1865) and Glossoceras gracile BARRANDE, 1865 (both N. kozlowskii Biozone). No ascocerids are known from the following $P$. dubius postfrequens Biozone. From the P. latilobus Biozone only one species, Pseudascoceras decipiens (LindströM, 1890), has been recorded (Zedník 2003; Text-fig. 3).

The highest abundance and diversity of ascocerids in the Prague Basin is reached in strata corresponding to the uppermost Ludfordian Stage and lower Př́dolí Series (P. fragmentalis, M. parultimus and M. ultimus biozones) (Zedník 2003; Text-fig. 3), where as many as nine ascocerid species occur: Aphragmites buchi BARRANDE, 1865, Aphragmites deshayesi BARRANDE, 1865, Aphragmites goldfussi BARRANDE, 1865, Aphragmites keyserlingi BARRANDE, 1865, Aphragmites amoenum Miller, 1932 (= Aphragmites keyserlingi var. amoena BARRANDE, 1865), Ascoceras bohemicum BARRANDE, 1855, Ascoceras bronni BARRAnde, 1865, Ascoceras murchisoni BARRANDE, 1865 and Pseudascoceras decipiens (LinDSTRÖM, 1890).

Stratigraphically youngest ascocerids in the Prague Basin are Pseudascoceras sp. (M. bouceki and M. transgrediens biozones) and Ascoceras murchisoni (M. transgrediens Biozone) (Zedník 2003; Text-fig. 3). No ascocerids are known from younger strata in Bohemia, or from any other region where ascocerids have been recorded.

The majority of Bohemian ascocerid species are entirely endemic to the Prague Basin. Only five out of the fourteen currently recognised species are known from elsewhere (Text-fig. 3), namely the Swedish island of Gotland (Lindström 1890): Ascoceras bohemicum, Ascoceras bronni, Ascoceras murchisoni, Glossoceras curtum MiLLER, 1932 (= Glossoceras gracile var. curta BARRANDE, 1865) and Pseudascoceras decipiens. Note, however, that some ascocerids reported from England (Holland 1999) as well as from German and Polish glacial erratics (Neben and Krüger 1973, Dzik 1984) may also be conspecific to some Bohemian species. 


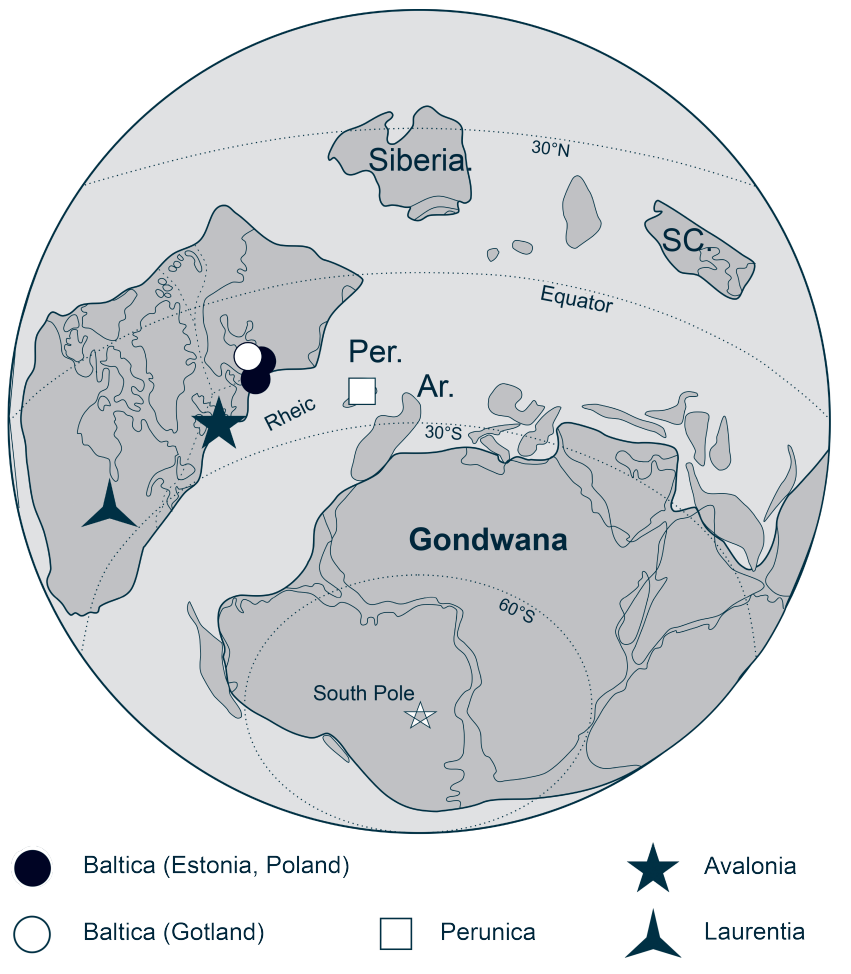

Text-fig. 5. Palaeogeographic distribution of ascocerid cephalopods during the late Silurian. Abbreviations: Ar. = Armorica, Per. $=$ Perunica, SC. $=$ South China. Map after Cocks and Torsvik (2002).

The ascocerid species known from Gotland appeared in the Prague Basin during an interval when the Perunica microcontinent was situated at relatively low-latitudes, in proximity to Baltica (Krŕž et al. 2003; Text-fig. 5). The proximity of Perunica to Baltica probably facilitated the exchange of ascocerid and other cephalopod faunas between the two regions (see also Manda 2008). In ascocerids, the exchange seems to have been especially intense during the Ludlow/Př́dolí transition interval, when the group also reached its maximum palaeogeographic dispersion and global diversity.

\section{Conclusions}

In the present paper, the history of research on the cephalopod Ascocerida is briefly summarised. Particular attention is paid to the studies of $\mathrm{J}$. Barrande $(1848,1855 \mathrm{a}$, b, $1865,1867,1877 \mathrm{a}, \mathrm{b})$, who was the first to describe ascocerid cephalopods and recognise the process of natural truncation of their juvenile shells. Barrande's collection contains over a hundred well-preserved specimens that have yet to be revised, while the extensive new material collected since Barrande's time has only been described as the subject of an unpublished MSc. thesis. At least four genera and fourteen species can be presently recognised within Bohemian ascocerid collections, two-thirds of which are fully endemic. Bohemian ascocerids show muscle scars (NM-L 9263, -L 42417, -L 13805; Text-fig. 4f, g), complete apertures (e.g. NM-L 9278; Text-fig. 4b, c) and the specimen NM-L 21655 (Text-fig. 4d) even preserves one chamber of the juvenile shell.
Five of the Bohemian ascocerid species were previously reported from strata of the Swedish island of Gotland (Textfig. 3). The appearance of these ascocerids in both regions during the late Silurian is probably a consequence of the increasing proximity of Perunica to Baltica at a relatively low latitude during that interval.

\section{Acknowledgements}

This article is dedicated to Vojtěch Turek for his enormous contribution to the understanding of early Palaeozoic cephalopods and fossils of the Barrandian area and, more personally, for always being a kind and patient teacher and a wonderful company.

I would like to thank Vojtěch Turek, Martin Valent(National Museum, Prague) and Petr Budil (Czech Geological Survey, Prague), who enabled access and assistance at the collections of ascocerid cephalopods at their respective institutions. I am very grateful also to Ronald L. Parsley (Tulane University, New Orleans), Petr Štorch (Academy of Sciences, Prague) and the reviewers, David H. Evans (Natural England, Bridgwater) and Štěpán Manda (Czech Geological Survey, Prague), for their valuable and constructive comments and revision of the manuscript. I am also indebted to Ladislav Zedník (Prague), who kindly provided many of the ascocerid specimens studied herein, and for the many valuable discussions related to ascocerid cephalopods. I thank Lenka Váchová (National Museum, Prague), who carefully photographed the type specimens of J. Barrande. Oldrich Fatka and Jakub Vodička (Faculty of Science, Charles University, Prague) are acknowledged for their help with literature and critical reading of the manuscript.

This work was financially supported by Ministry of Culture of the Czech Republic (DKRVO 2019-2023/2.IV.a, National Museum, 00023272).

\section{References}

Aubrechtová, M., Meidla, T. (2016): The oldest ascocerid cephalopod from the Silurian of Estonia and notes on the biogeography of the order Ascocerida (class Cephalopoda). - Estonian Journal of Earth Sciences, 65(2): 98-104. https://doi.org/10.3176/earth.2016.07

Barrande, J. (1848): Eine weitere Sendung von Cephalopoden aus den silurischen Schichten von Böhmen (showed by F. Hauer). - Berichte über Mittheilungen von Freunden der Naturwissenschaften in Wien, 4: 208-211.

Barrande, J. (1855a): Sur les Ascoceras. Prototype des Nautilides. - Bulletin de la Societé Géologique de France, série 2, 12(1): 157-177.

Barrande, J. (1855b): Ascoceras, der Prototyp von Nautilus. - Neues Jahrbuch für Mineralogie, Geognosie, Geologie und Petrefaktenkunde, 1855: 257-285.

Barrande, J. (1860): Troncature normale ou périodique de la coquille dans certains céphalopodes paléozoiques. Bulletin de la Societé géologique de France, séries 2, 17: 573-601.

Barrande, J. (1865): Systême silurien du centre de la Bohême, Iére partie: Recherches Paléontologiques, vol. 
II., Classe de Mollusques, Ordre des Céphalopodes. Íre Série: Planches 1 à 107. - Chez l'auteur et éditeur, Prague, Paris, 6 unnumbered pages, pls 1-107.

Barrande, J. (1867): Systême silurien du centre de la Bohême, I ${ }^{\text {re }}$ partie: Recherches Paléontologiques, vol. II., Texte, Classe de Mollusques, Ordre des Céphalopodes. - Chez l'auteur et éditeur, Prague, Paris, xxxvi + 712 pp.

Barrande, J. (1877a): Systême silurien du centre de la Bohême, I ${ }^{\text {ére }}$ partie: Recherches Paléontologiques, vol. II., Classe de Mollusques, Ordre des Céphalopodes. Supplément et Série tardive. Planches 461 à 544. - Chez l'auteur et éditeur, Prague, Paris, pls 461-544.

Barrande, J. (1877b): Systême silurien du centre de la Bohême, I ${ }^{\text {re }}$ partie: Recherches Paléontologiques, vol. II., Classe de Mollusques, Ordre des Céphalopodes. Supplément et Série tardive. Texte. - Chez l'auteur et éditeur, Prague, Paris, viii +297 pp.

Billings, E. (1857): New species of fossils from Silurian rocks of Canada. - Report for the Years 1853-1856, Geological Survey of Canada, pp. 245-345.

Billings, E. (1865): Palaeozoic fossils: Vol. 1, containing descriptions and figures of new or little known species of organic remains from the Silurian rocks. - Report for the Years 1861-1865, Geological Survey of Canada, Special Report, pp. 1-426.

https://doi.org/10.4095/222588

Billings, E. (1866): Catalogues of the Silurian Fossils of the Island of Anticosti: with Descriptions of Some New Genera and Species. - Geological Survey of Canada, Dawson Brothers, Montreal, Bailliere, London, 93 pp. https://doi.org/10.4095/216072

Blake, J. F. (1882): A Monograph of the British Fossil Cephalopods, Part 1. Introduction and Silurian Species. - J. van Voorst, London, 248 pp.

Cichowolski, M., Uriz, N. J., Alfaro, M. B., Inchausti, J. G. (2018): Ascocerid cephalopods from the Hirnantian? - Llandovery stages of the southern Paraná Basin (Paraguay, South America): first record from high paleolatitudes. - Journal of Paleontology, 93(1): 37-47. https://doi.org/10.1017/jpa.2018.59

Chlupáč, I. (1998): Devonian. - In: Chlupáč, I., Havlíček, V., Kř́žž, J., Kukal, Z., Štorch, P. (eds), Palaeozoic of the Barrandian (Cambrian to Devonian). Czech Geological Survey, Prague, pp. 101-148.

Chlupáč, I., Jaeger, H., Zikmundová, J. (1972): The SilurianDevonian boundary in the Barrandian. - Bulletin of Canadian Petroleum Geology, 20(1): 104-174.

Chlupáć, I., Vacek, F. (2003): Thirty years of the first international stratotype: The Silurian-Devonian boundary at Klonk and its present status. - Episodes, 26(1): 10-15.

Cocks, L. R. M., Torsvik, T. H. (2002): Earth geography from 500 to 400 million years ago: a faunal and palaeomagnetic review. - Journal of the Geological Society, 159(6): 631-644. https://doi.org/10.1144/0016-764901-118

Cocks, L. R. M., Torsvik, T. H. (2006): European geography in a global context from the Vendian to the end of the Palaeozoic. - Memoirs of the Geological Society of London, 32: 83-95.

https://doi.org/10.1144/GSL.MEM.2006.032.01.05
Dzik, J. (1984): Phylogeny of the Nautiloidea. Palaeontologia Polonica, 45: 1-203.

Fatka, O., Brocke, R., Wilde, V. (2003): Organic-walled microfossils at the Silurian/Devonian boundary stratotype (Klonk near Suchomasty, Barrandian area, Czech Republic). - INSUGEO, Serie Correlación Geológica, 18: 125-128. https://doi.org/10.1144/SP325.4

Fatka, O., Mergl, M. (2009): The "microcontinent" Perunica - status and story 15 years after its conception. - Special Publication, Geological Society, London, 325: 65-101.

Ferretti, A., Kř́̌ž, J. (1995): Cephalopod limestone biofacies in the Silurian of the Prague Basin, Bohemia. - Palaios, 10(3): 240-253. https://doi.org/10.2307/3515255

Flower, R. H. (1941): Development of the Mixochoanites. Journal of Paleontology, 15: 523-548.

Flower, R. H. (1946): Ordovician cephalopods from the Cincinnati region. Part 1. - Bulletins of American Paleontology, 29(116): 3-547.

Flower, R. H. (1952): New Ordovician cephalopods from eastern North America. - Journal of Paleontology, 26: 24-59.

Flower, R. H. (1963): New Ordovician Ascoceratida. Journal of Paleontology, 37(1): 69-85.

Flower, R. H., Kummel, B. (1950): A classification of the Nautiloidea. - Journal of Paleontology, 24: 604-616.

Foerste, A. F. (1928): Some hitherto unfigured Ordovician cephalopods from Anticosti Island. - Transactions of the Royal Society of Canada, $3^{\text {rd }}$ Series, 22: 223-234.

Foerste, A. F. (1929): Cephalopods of the Red River Formation of Southern Manitoba. - Denison University Bulletin, Journal of the Scientific Laboratories, 24: 129235.

Foerste, A. F. (1930): Port Byron and other Silurian cephalopods. - Denison University Bulletin, Journal of the Scientific Laboratories, 23: 1-110.

Foerste, A. F. (1932): Black River and other cephalopods from Minnesota, Wisconsin, Michigan, and Ontario (Part I). - Journal of the Scientific Laboratories, Denison University Bulletin, 27: 40-147.

Foerste, A. F., Savage, T. E. (1927): Ordovician and Silurian cephalopods of the Hudson Bay area. Denison University Bulletin, Journal of the Scientific Laboratories, 22: 1-107.

Frey, R. C. (1985): A well-preserved specimen of Schuchertoceras (Cephalopoda, Ascocerida) from the Upper Ordovician (basal Richmondian) of Southwest Ohio. - Journal of Paleontology, 59: 1506-1511.

Frýda, J., Manda, Š. (2013): A long-lasting steady period of isotopically heavy carbon in the late Silurian ocean: evolution of the $\delta^{13} \mathrm{C}$ record and its significance for an integrated $\delta^{13} \mathrm{C}$, graptolite and conodont stratigraphy. Bulletin of Geosciences, 88(2): 463-482. https://doi.org/10.3140/bull.geosci.1436

Furnish, W. M., Glenister, B. F. (1964): Nautiloidea - Ascocerida. - In: Moore, R. C. (ed.), Treatise on invertebrate paleontology. Part K. Mollusca 3. Endoceratoidea, Actinoceratoidea, Nautiloidea, Bactritoidea. GSA and University of Kansas Press, Lawrence, Kansas, pp. K261-K277. 
Havlíček, V. (1981): Development of a linear sedimentary depression exemplified by the Prague Basin(OrdovicianMiddle Devonian; Barrandian area - central Bohemia). Sborník geologických věd, Geologie, 35: 7-48.

Havlíček, V. (1982): Ordovician in Bohemia - development of the Prague Basin and its benthic communities. Sborník geologických věd, Geologie, 37: 103-136.

Havlíček, V. (1998): Ordovician. - In: Chlupáč, I., Havlíček, V., Kř́žz, J., Kukal, Z., Štorch, P. (eds), Palaeozoic of the Barrandian (Cambrian to Devonian). Czech Geological Survey, Prague, pp. 41-79.

Havlíček, V., Vaněk, J., Fatka, O. (1994): Perunica microcontinent in the Ordovician (its position within the Mediterranean Province, series division, benthic and pelagic associations). - Sborník geologických věd, Geologie, 46: 23-56.

Holland, C. H. (1999). The nautiloid cephalopod order Ascocerida in the British Silurian. - Palaeontology, 42(4): 683-689. https://doi.org/10.1111/1475-4983.00092

Hyatt, A. (1883-1884): Genera of fossil cephalopods. Proceedings of the Boston Society of Natural History, 22: 253-338.

Kaljo, D. (1970): Mollyuski [Mollusks]. - In: Kaljo, D. (ed.), Silur Estonii [The Silurian of Estonia]. - Valgus, Tallinn, pp. 150-153. (in Russian)

Kesling, R. V. (1961): A new species of Billingsites, an ascoceratid Cephalopod, from the Upper Ordovician Ogontz Formation of Michigan. - Contribution from the Museum of Paleontology, University of Michigan, 17: 77-121.

Kesling, R. V. (1962): Billingsites noquettensis FOERSTE 1926, non Kesling 1961. - Journal of Paleontology, 36: 612-613.

King, A. H., Evans, D. H. (2019): High-level classification of the nautiloid cephalopods: a proposal for the revision of the Treatise Part K. - Swiss Journal of Palaeontology, 138(1): 65-85. https://doi.org/10.1007/s13358-019-00186-4

Kröger, B. (2007): Concentrations of juvenile and small adult cephalopods in the Hirnantian cherts (Late Ordovician) of Porkuni, Estonia. - Acta Palaeontologica Polonica, 52: 591-608.

Kröger, B. (2013): The cephalopods of the Boda Limestone, Late Ordovician, of Dalarna, Sweden. - European Journal of Taxonomy, 41: 1-110. https://doi.org/10.5852/ejt.2013.41

Kříž, J. (1989): Př́idolí Series in the Prague Basin (Barrandian area, Bohemia). - In: Holland, C. H., Bassett, M. G. (eds), A global standard for the Silurian System. National Museum of Wales, Geological Series, 9: 90-100.

Kříž, J. (1991): The Silurian of the Prague Basin (Bohemia) - tectonic, eustatic and volcanic controls on facies and faunal development. - In: Bassett, M. G., Lane, P. D., Edwards, D. (eds), The Murchison Symposium: proceedings of an international conference on the Silurian System. Special Papers in Palaeontology, 44: 179-203.

Kříž, J. (1992): Silurian Field Excursions. Prague Basin (Barrandian), Bohemia. - National Museum of Wales, Geological Series, 13: 1-110.
Kříž, J. (1998a): Silurian. - In: Chlupáč, I., Havlíček, V., Kř́žz, J., Kukal, Z., Štorch, P. (eds), Palaeozoic of the Barrandian (Cambrian to Devonian). Czech Geological Survey, Prague, pp. 79-98.

Kř́žž, J. (1998b): Recurrent Silurian-lowest Devonian cephalopod limestones of Gondwanan Europe and Perunica. - In: Landing, E., Johnson, M. E. (eds): Silurian cycles: Linkages of dynamic stratigraphy with atmospheric, oceanic, and tectonic changes. New York State Museum Bulletin, 491: 183-198.

Kř́̌ž, J. (1999): Cephalopod limestone biofacies on the northern slopes of the Silurian volcanic archipelago in the Prague Basin containing re-described benthic Cardiola donigala-Slava cubicula Community (Bivalvia, Barrandian, Bohemia). - Journal of Geosciences, 44(12): 159-165. (in English with Czech summary)

Kř́̌ž, J., Degardin, J. M., Ferretti, A., Hansch, W., GutiérrezMarco, J. C., Paris, F., Piçarra, J., Robardet, M., Schönlaub, H., Serpagli, E. (2003): Silurian stratigraphy and paleogeography of north Gondwanan and Perunican Europe. - New York State Museum Bulletin, 493: 105178.

Kř́̌ž, J., Dufka, P., Jaeger, H., Schönlaub, H. P. (1993): The Wenlock/Ludlow boundary in the Prague Basin (Bohemia). - Jahrbuch der Geologischen Bundesanstalt, 136(4): 809-839.

Kř́̌ž, J., Jaeger, H., Paris, F., Schönlaub, H. P. (1986): Př́idolí - the fourth subdivision of the Silurian. - Jahrbuch der Geologischen Bundesanstalt, 129(2): 291-360.

Kuhn, O. (1949): Lehrbuch der Paläozoologie. - E. Schweizerbart, Stuttgart, 326 pp.

Lindström, G. (1890): The Ascoceratidae and the Lituitidae of the Upper Silurian formation of Gotland. - Kungliga Svenska Vetenskaps-Akademiens Handlingar, 23: 1-54.

Manda, Š. (2008): Palaeoecology and palaeogeographic relations of the Silurian phragmoceratids (Nautiloidea, Cephalopoda) of the Prague Basin (Bohemia). - Bulletin of Geosciences, 83(1): 39-62.

https://doi.org/10.3140/bull.geosci.2008.01.039

Manda, Š., Křŕž, J. (2006): Environmental and biotic changes in subtropical isolated carbonate platforms during the Late Silurian Kozlowskii Event, Prague Basin. - GFF, 128(2): 161-168. https://doi.org/10.3140/bull.geosci.2008.01.039

Manda, Š., Kříž, J. (2007): New cephalopod limestone horizon in the Ludlow (Gorstian, lower L. scanicus Biozone) of the Prague Basin (Bohemia, Perunica). Bollettino della Società Paleontologica Italiana, 46(1): $33-45$. https://doi.org/10.1080/11035890601282161

Manda, Š., Frýda, J. (2010): Silurian-Devonian boundary events and their influence on cephalopod evolution: evolutionary significance of cephalopod egg size during mass extinctions. - Bulletin of Geosciences, 85(3): 513-540. https://doi.org/10.3140/bull.geosci.1174

Manda, Š., Štorch, P., Slavík, L., Frýda, J., Kř́íž, J., Tasáryová, Z. (2012): The graptolite, conodont and sedimentary record through the late Ludlow Kozlowskii Event (Silurian) in the shale-dominated succession of Bohemia. - Geological Magazine, 149(3): 507-531. https://doi.org/10.1017/S0016756811000847 
Miller, A. K. (1932): The mixochoanitic cephalopods. University of Iowa Studies, Studies in Natural History, 14: $1-67$.

Mutvei, H. (2012): Siphuncular structure in Silurian discosorid and ascocerid nautiloids (Cephalopoda) from Gotland, Sweden: implications for interpretation of mode of life and phylogeny. - GFF, 134(1): 27-37. https://doi.org/10.1080/11035897.2012.654507

Mutvei, H. (2013): Characterization of nautiloid orders Ellesmerocerida, Oncocerida, Tarphycerida, Discosorida and Ascocerida: new superorder Multiceratoidea. - GFF 135(2): 171-183. https://doi.org/10.1080/11035897.2013.801034

Neben, W., Krüger, H. H. (1973): Fossilien ordovicischer und silurischer Geschiebe. - Staringia, 2(1): 3-73.

Newell, F. H. (1888): Niagara Cephalopods from Northern Indiana. - Proceedings of the Boston Society of Natural History, 23: 466-486.

Parsley, R. L., Lawson, M. H., Pojeta, J., Jr. (2018): A practical and historical perspective on the how and why of whitening fossil specimens and casts as a precursor to their photography. - Fossil Imprint, 74(3-4): 237-244. https://doi.org/10.2478/if-2018-0016

Prant, F., Přibyl, A. (1948): Revise různorepých (Eurypterida) $\mathrm{z}$ českého siluru [Revision of the Bohemian Silurian Eurypterida]. - Rozpravy Státního geologického ústavu Československé Republiky, 10: 1-116. (in Czech and English)

Salter, J. W. (1858): On a new genus of Cephalopoda, Tretoceras (Orthoceras bisiphonatum, SOWERBY); and on the occurrence of the Genus Ascoceras, BARRANDE, in Britain. - Quarterly Journal of the Geological Society of London, 14: 177-180. https://doi.org/10.1144/GSL.JGS.1858.014.01-02.24

Slavík, L., Štorch, P., Manda, Š., Frýda, J. (2014): Integrated stratigraphy of the Ludfordian in the Prague Synform. GFF, 136(1): 238-242. https://doi.org/10.1080/11035897.2013.851733

Storch, P. (1986): Ordovician-Silurian boundary in the Prague Basin (Barrandian area, Bohemia). - Sborník geologických věd, Geologie, 41: 69-103.

Storch, P. (1994): Graptolite biostratigraphy of the lower Silurian (Llandovery and Wenlock) of Bohemia. Geological Journal, 29: 137-165. https://doi.org/10.1002/gj.3350290204

Štorch, P. (1995a): Biotic crises and post-crisis recoveries recorded by Silurian planktonic graptolite faunas of the Barrandian area (Czech Republic). - Geolines, 3: 59-70.

Štorch, P. (1995b): Upper Silurian (upper Ludlow) graptolites of the $N$. inexpectatus and $N$. kozlowskii biozones from Kosov Quarry near Beroun (Barrandian area, Bohemia). Věstník Českého geologického ústavu, 70(4): 65-89.

Štorch, P. (2006): Facies development, depositional settings and sequence stratigraphy across the Ordovician-Silurian boundary: a new perspective from the Barrandian area of the Czech Republic. - Geological Journal, 41(2): 163-192. https://doi.org/10.1002/gj.1038

Štorch, P. (2015): Graptolites from the Rhuddanian-Aeronian boundary interval (Silurian), Prague Synform, Czech Republic. - Bulletin of Geosciences, 90(4): 841-891. https://doi.org/10.3140/bull.geosci.1568
Štorch, P., Manda, Š., Loydell, D. K. (2014): The early Ludfordian leintwardinensis graptolite Event and the Gorstian-Ludfordian boundary in Bohemia (Silurian, Czech Republic). - Palaeontology, 57(5): 1003-1043. https://doi.org/10.1111/pala.12099

Štorch, P., Manda, Š., Tasáryová, Z., Frýda, J., Chadimová, L., Melchin, M. J. (2018): A proposed new global stratotype for Aeronian Stage of the Silurian System: Hlásná Třebaň section, Czech Republic. - Lethaia, 51(3): 357-388. https://doi.org/10.1111/pala.12099

Strand, T. (1933): The Upper Ordovician cephalopods of the Oslo area. - Norsk Geologiske Tidsskrift 14: 1-117.

Sweet, W. C. (1958): The middle Ordovician of the Oslo region, Norway. 10. Nautiloid cephalopods. - Norsk Geologisk Tidsskrift, 38: 1-176.

Sweet, W. C. (1959): Muscle attachment impressions of some Paleozoic nautiloid cephalopods. - Journal of Paleontology, 33: 293-305.

Tasáryová, Z., Janoušek, V., Frýda, J. (2018): Failed Silurian continental rifting at the NW margin of Gondwana: evidence from basaltic volcanism of the Prague Basin (Teplá-Barrandian Unit, Bohemian Massif). International Journal of Earth Sciences, 107(4): 12311266. https://doi.org/10.1007/s00531-017-1530-5

Tasáryová, Z., Schnabl, P., Č́žzová, K., Pruner, P., Janoušek, V., Rapprich, V., Štorch, P., Manda, Š., Frýda, J., Trubač, J. (2014): Gorstian palaeoposition and geotectonic setting of Suchomasty Volcanic Centre (Silurian, Prague Basin, Teplá-Barrandian Unit, Bohemian Massif). GFF, 136: 262-265. https://doi.org/10.1080/11035897.2013.879735

Teichert, C. (1988): Main features of cephalopod evolution. - In: Clarke, M. R., Trueman, E. R. (eds), The Mollusca. Vol. 12: Paleontology and Neontology of Cephalopods. Academic Press, San Diego, pp. 11-79. https://doi.org/10.1016/B978-0-12-751412-3.50009-7

Turek, V., Manda, Š. (2012): “An endocochleate experiment” in the Silurian straight-shelled cephalopod Sphooceras. Bulletin of Geosciences, 87: 767-813. https://doi.org/10.3140/bull.geosci.1335

Vacek, F., Slavík, L., Sobień, K., Čáp, P. (2018): Refining the late Silurian sea-level history of the Prague Syncline - a case study based on the Prídolí GSSP (Czech Republic). - Facies, 64: 30 (16 pp.). https://doi.org/10.1007/s10347-018-0542-3

Vacek, F., Žák, J. (2017): A lifetime of the Variscan orogenic plateau from uplift to collapse as recorded by the Prague Basin, Bohemian Massif. - Geological Magazine, 156(3): 485-509. https://doi.org/10.1017/S0016756817000875

Westermann, G. E. G. (1998): Life habits of nautiloids. In: Savazzi, E. (ed.), Functional morphology of the invertebrate skeleton. Wiley and Sons, New York, pp. 263-298.

Whiteaves, J. F. (1884): On some new, imperfectly characterized or previously unrecorded species of fossils from the Guelph formation of Ontario. - Palaeozoic Fossils, Geological Survey of Canada, 3: 1-43. https://doi.org/10.4095/131596 
Worthen, A. H. (1890): Description of fossil invertebrates. Geological Survey of Illinois, 8, pt. II, sec. I: 69-154.

Zedník, L. (2003): Revize rodu Ascoceras BARRANDE, 1847 ze siluru pražské pánve [Revision of the genus Ascoceras Barrande, 1847 from the Silurian of the Prague Basin]; Diplomová práce [MSc. thesis]. - MS, Ústav geologie a paleontologie, Př́rodovědecká fakulta, Univerzita Karlova [Institute of Geology and Palaeontology, Faculty of Science, Charles University], Prague, the Czech Republic, 76 pp. (in Czech) (copy at the Geological Library, Faculty of Science)

Zittel, K. A. von (1900): Text-book of Paleontology (translated and edited by Ch. R. Eastman). - Macmillan and Co., London, New York, 706 pp. (Hyatt, A.: Suborder B. Mixochoanites Hyatt, pp. 515-516) 